\title{
Subaerial terminoglacial fans III: overview of sedimentary characteristics and depositional model
}

\author{
T. Zieliński ${ }^{1} \&$ A.J. van Loon ${ }^{2}$ \\ 1 corresponding author; Silesian University, Department of Earth Sciences, Bẹdzińska 60, 41-200 \\ Sosnowiec, Poland; e-mail: zielu@us.edu.pl \\ ${ }^{2}$ Geocom, P.O. Box 336, 6860 AH Oosterbeek, the Netherlands; e-mail: geocom@wxs.nl
}

Received: 15 January 1999; accepted: 29 November 1999

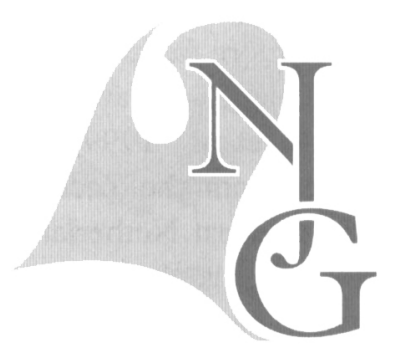

\begin{abstract}
A general model is presented for the small type of fans (not to be confused with sandurs) that develop subaerially in the zone immediately before an ice front. These fans have in common with other fans that a proximal, a middle and a distal subenvironment - with distinctly different sedimentary facies - can be distinguished. The characteristics of these fans differ in several respects, however, from those formed under other conditions, particularly by the high proportion of mass-flow deposits in the proximal part, by the relative scarcity of fine particles in the middle fan, and by the relatively uniform character of the sediments in the distal fan.

The special character of this type of fan is ascribed to the interaction of a continuously changing distance between the ice front and the fan (as a result of alternating phases of ice advance and ice retreat), its position that may be surrounded by ice for a large part, and the irregular supply of debris-laden meltwater that comes sometimes even in the form of more or less catastrophic floods.

Due to the fact that terminoglacial fans have a good preservation potential only during phases of ice retreat, these fas tend to show a slight fining-upward tendency. The slope of terminoglacial fans tends to be more gentle (rarely over $2-5^{\circ}$ ) than that of fans formed under different conditions.
\end{abstract}

Keywords: depositional model, facies analysis, glacial fan, Poland, terminoglacial zone, Weichselian

\section{Introduction}

The analysis of fans formed in the narrow zone just in front of an ice mass ('terminoglacial fans', following the nomenclature of Brodzikowski \& Van Loon, 1987, 1991) helps in the reconstruction of the previous extent of such ice masses. Analysis of terminoglacial fans of Pleistocene age therefore plays a significant part in palaeogeographic reconstructions of Pleistocene glaciations, particularly in previously glaciated lowland areas.

It appears that much confusion exists regarding the term 'fan', and also that terminoglacial fans are confused with sandurs (see, for instance, Leeder, 1999). There are, however, important differences between sandurs (also known as 'glacial outwash plains') and terminoglacial fans. Good overviews with useful dis- cussions about what fans are (and of what they are not) have been provided by Blair \& McPherson (1994a,b). We want to emphasize that our investigations were restricted to fans and did not deal with sandurs.

We carried out sedimentological analyses of twenty-seven fans in NE Poland (Fig. 1), with emphasis on semi-quantitative investigations of grain size and sedimentary structures. The fans had been formed just in front of the Weichselian ice sheet. In two earlier contributions, we presented the semi-quantitative analyses carried out in the proximal subenvironment (Zieliński \& Van Loon, 1998) as well as in the middle and distal subenvironments (Zieliński \& Van Loon, 1999). In these contributions, we distinguished three sedimentary facies of the proximal terminoglacial fan. Facies $P-1$ is dominated by diamicts and contains two 


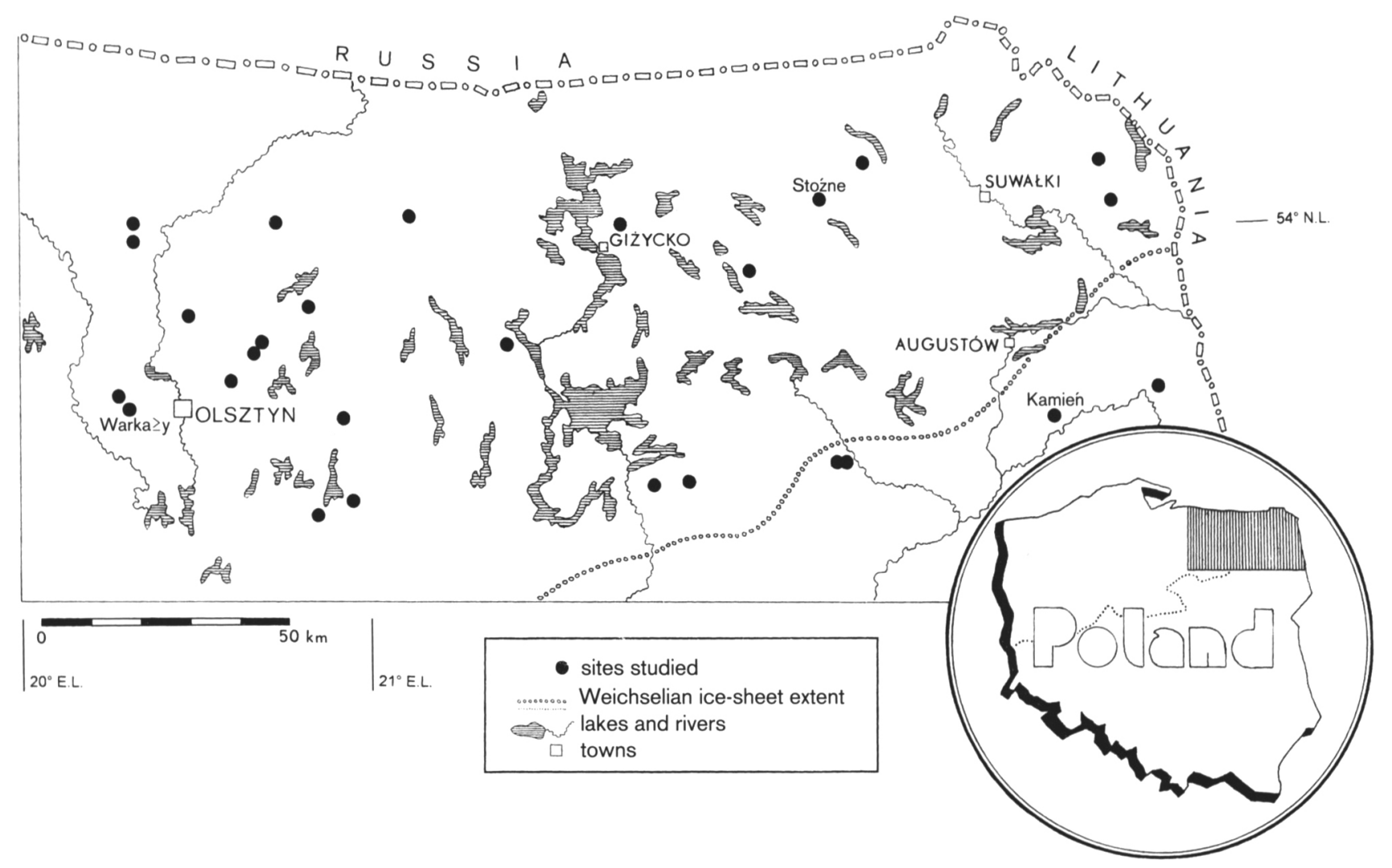

Fig. 1. Location of study area and of sites investigated.

subfacies: $P-1 a$ formed by flowtills and gravel-bed streams, and $P-1 b$ consisting of reworked flowtills. Facies $P-2$ is built up by beds of gravelly sand and is subdivided into two subfacies: $P-2 a$ is formed by sheetflows and $P-2 b$ by sheetflows and channelized flows. Facies $P-3$ includes gravel and sand beds; its subfacies were formed by catastrophic, hyperconcentrated flows $(P-3 a)$ and in gravel-bed channels $(P-3 b)$ (Fig. 2). The middle fan environment comprises two - mainly sandy - facies: $M-1$ is formed in sand-bed braided channels (Fig. 3), and $M-2$ is formed by sand-bed sheetflows. Only one fan facies is found in the distal environment $(D)$. This facies consists of fine sands and silts (Fig. 4) deposited by low-energy sheetflows and by settling in ephemeral ponds. We refer the reader to the just mentioned contributions on these fans for more details about the granulometric data, the sedimentary structures and the interpretation of the processes involved, as well as for further details and introductory remarks concerning the general conditions under which subaerial terminoglacial fans are formed.

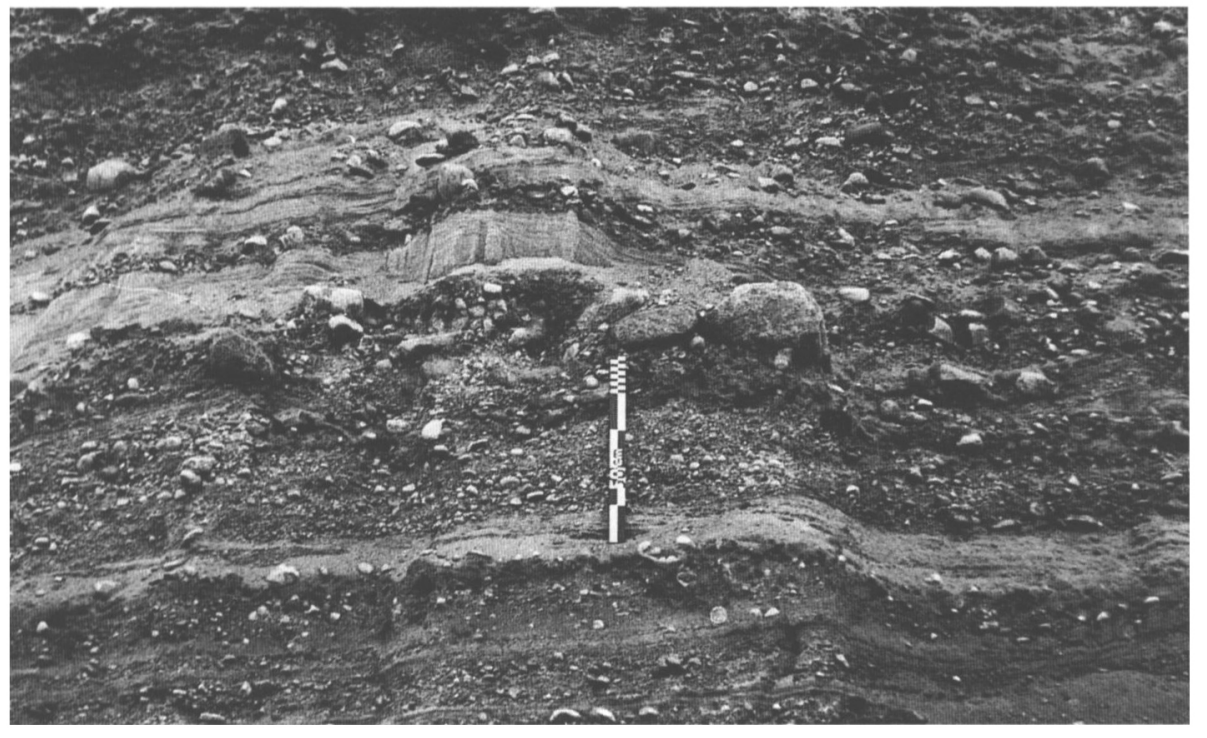

Fig. 2. Deposit characteristic of subfacies P-3b. Medium-scale gravel beds (both massive and crudely stratified) intercalate with sheet-shaped beds consisting of horizontally laminated sands. The scale is $0.5 \mathrm{~m}$ long. Stożne site. 


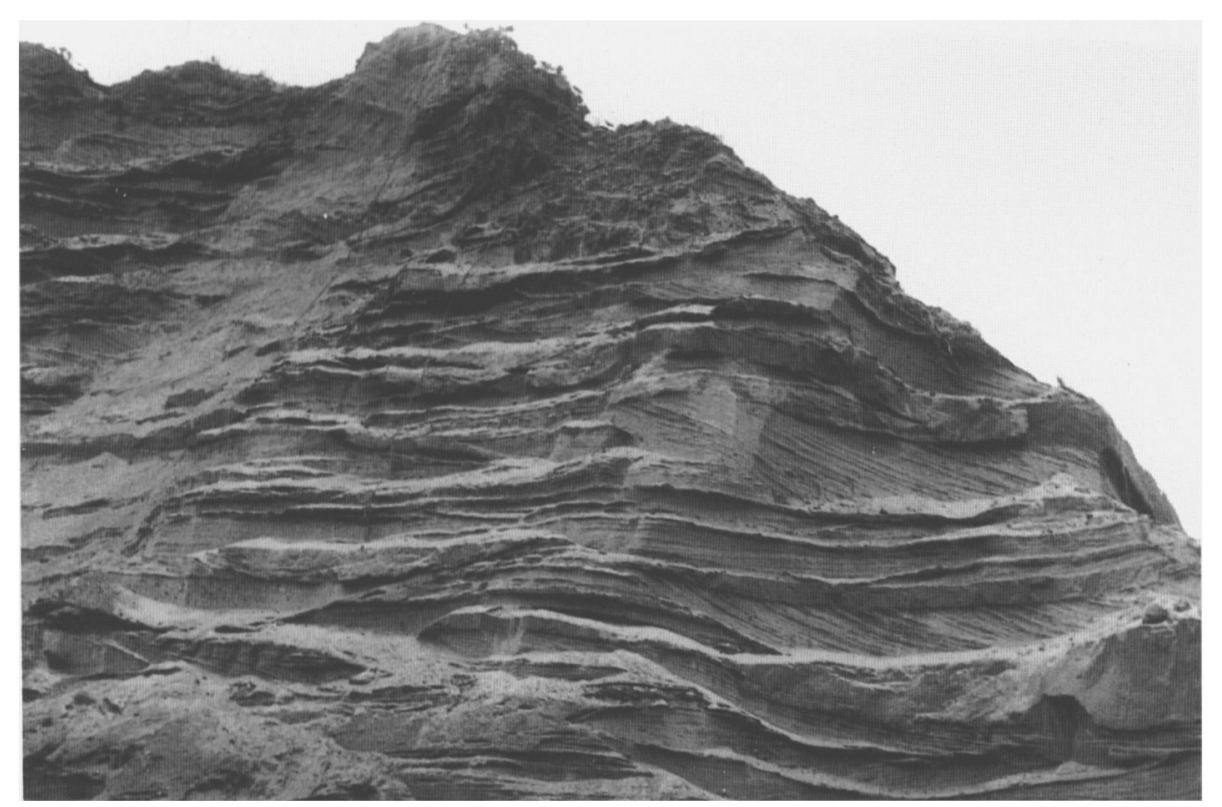

Fig. 3. Deposit characteristic of relatively proximal deposits of facies $M-1$. The gravels and sands were deposited in braided channels. Section approx. $3 \mathrm{~m}$ high. Kamień site.

Most terminoglacial fans are $10-30 \mathrm{~m}$ thick, most commonly $20-25 \mathrm{~m}$. They show comparable vertical developments, but rarely completely or exactly according to an 'ideal' scheme. Combining data makes it possible, however, to establish composite sections that show all the relevant aspects in a logical (often repeated) succession. Such successions comprise several facies and show characteristic features that reflect the qualitative and quantitative changes in the transporting and depositional agents, and thus in the de-

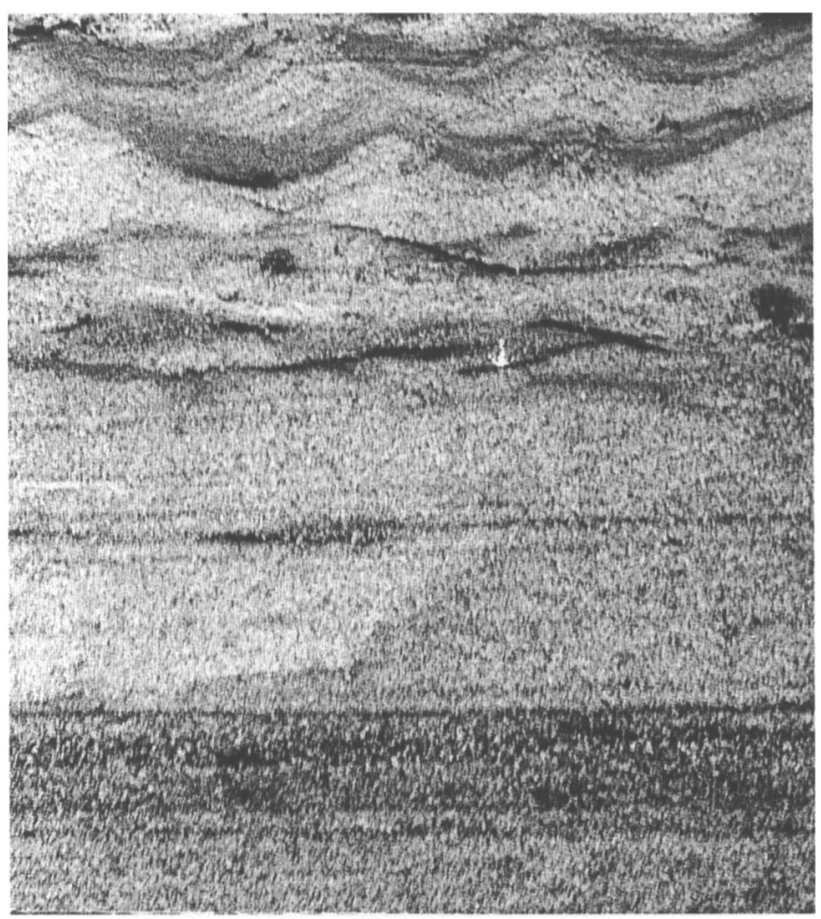

Fig. 4. Deposit characteristic of subenvironment D, showing a rhythmic alternation of sands with ripple-derived cross-lamination and horizontally laminated silts. The section is approx. $30 \mathrm{~cm}$ thick. Warkaty site. positional environment. It should be noted that sedimentary and erosional processes in the terminoglacial subenvironment are exceptionally changeable.

The present study focuses on the framework in which the processes took place that must be held responsible for the aggradation of the terminoglacial fans. The objective is the development of a model that will improve the understanding of the genesis of fans formed under these conditions, facilitate their recognition in the field, and deepen the insight into the erosional and depositional processes that play a part in the transformation of true moraines (i.e., glacial tills) into fans.

\section{General model}

Debris left behind by stagnant and retreating glaciers is affected by a number of superficial processes that result, partly during and partly after the building up of marginal moraines, in the formation of fans under terminoglacial conditions. The main process involved is transport under the influence of meltwater - both hydraulic transport of individual grains by meltwater currents and transport by various types of mass-flow processes.

\section{Subenvironments and energy conditions}

The processes in the terminoglacial zone responsible for the formation of fans, like those under other environmental conditions, result in the surface of the fan having a decreasing slope. The energy conditions therefore diminish from the apex downwards. This is reflected in a gradual decrease in grain size, which allows three subenvironments to be distinguished: a 
proximal subenvironment in which gravels dominate, a middle subenvironment with mainly sand (but with some gravel), and a distal subenvironment of predominantly sand and finer material. The sediments in the three subenvironments differ in their sedimentological characteristics (bedforms, structures, etc.), thus reflecting the various transporting and depositional conditions.

The proximal subenvironment is represented by the coarsest sediments (gravel and coarse sand). Mass-flow processes (both subaerial and subaqueous) play a dominant part (cf. Selby, 1994), due to the water-saturated character of most sediments under these conditions. The resulting clayey flowtills and gravelly debris-flow deposits commonly undergo subsequent reworking by currents (Fig. 5). High-energy conditions during large meltwater floods, in combination with steep slopes, result in unchannelized transport of meltwater rich in gravel. Sudden outbursts of huge amounts of meltwater result in high-density streams through the channels, which sometimes be-
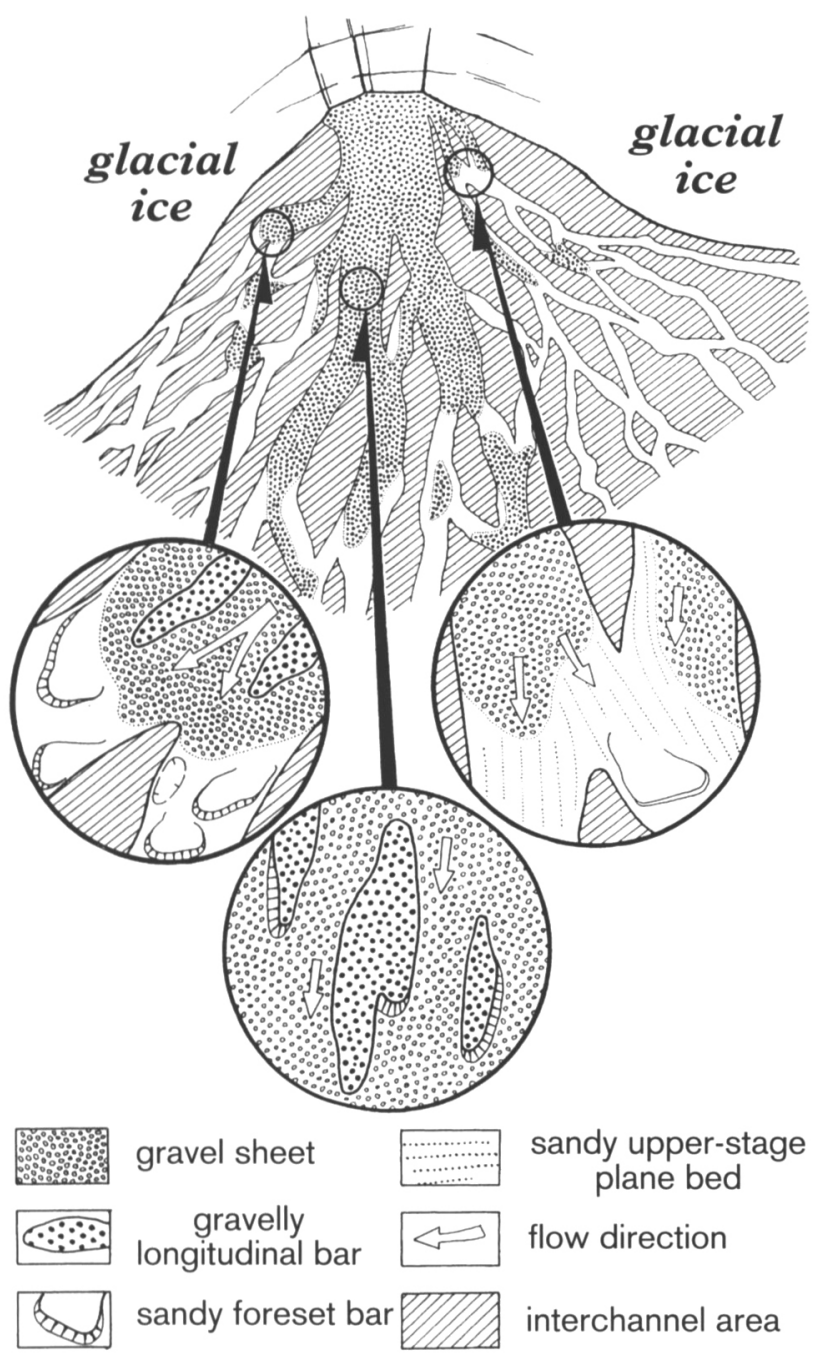

gravel sheet

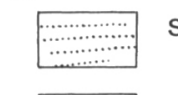

sandy upper-stage plane bed

\section{gravelly longitudinal bar \\ $\leftrightarrow$ \\ flow direction \\ sandy foreset bar \\ interchannel area}

Fig. 5. Generalised palaeoenvironmental model of the proximal fan dominated by gravel-bed streams (subfacies $P-3 b$ ). come deeply incised. In such channels with transport transitional between mass flow and stream flow instantaneous deposition can develop. Quieter conditions result in braided streams, but are of minor importance with respect to the aggradation of the fan.

The middle subenvironment consists predominantly of sands. These are deposited by both sheetfloods and braided streams (Fig. 6). Transport and deposition take place in a more uniform way than in the proximal subenvironment (as the effects of sudden outbursts of meltwater from the ice-sheet become less catastrophic with distance regarding both discharge and stream power), but still largely under upper plane-bed conditions.

The distal subenvironment is characterised by accretion of sandy/silty sediments. Ephemeral, shallow streams and ponds are the main depositional sites (Fig. 7). The energy of the flows has decreased so much in this subenvironment that many sands show current ripples formed in the lower flow regime, though some sands are still deposited under upper

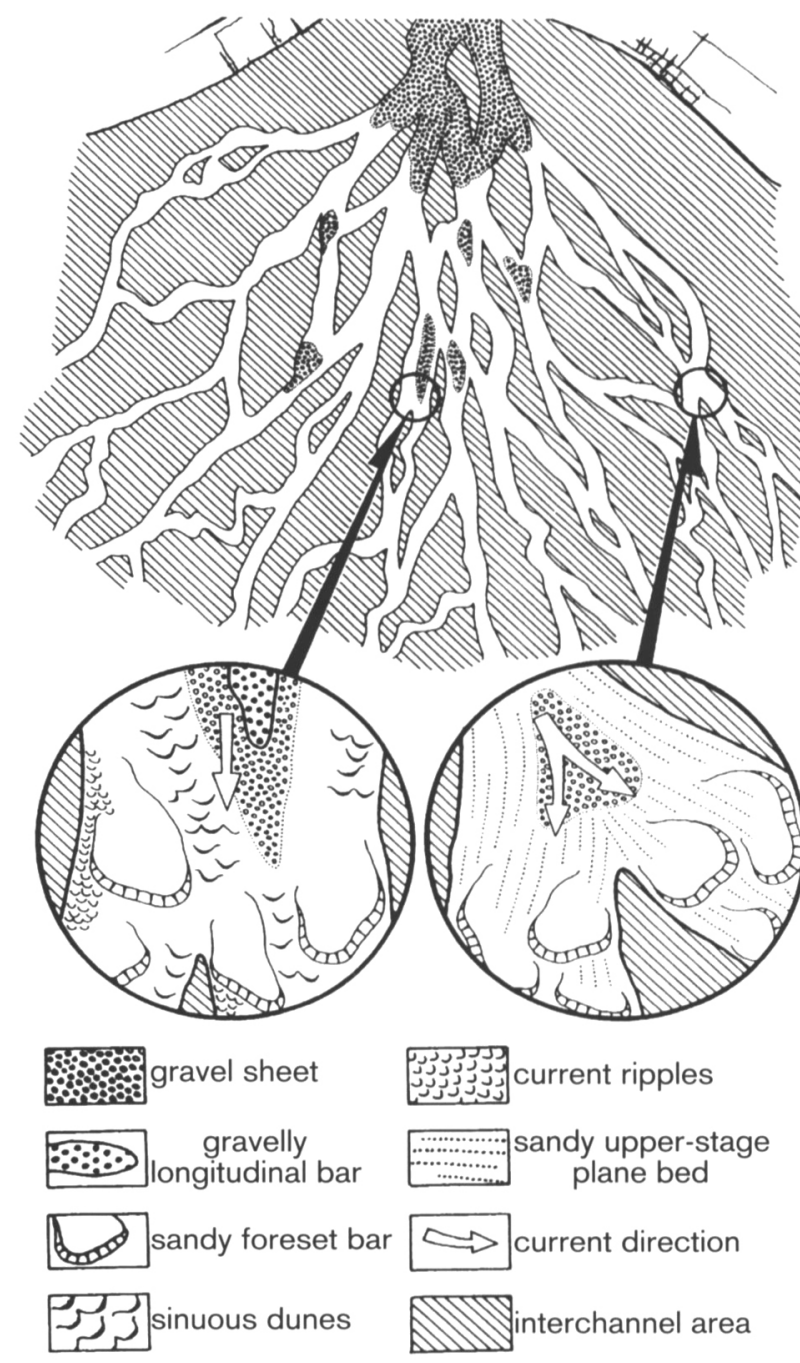

Fig. 6. Generalised palacoenvironmental model of the middle fan dominated by sand-bed streams (facies $M-1$ ). 


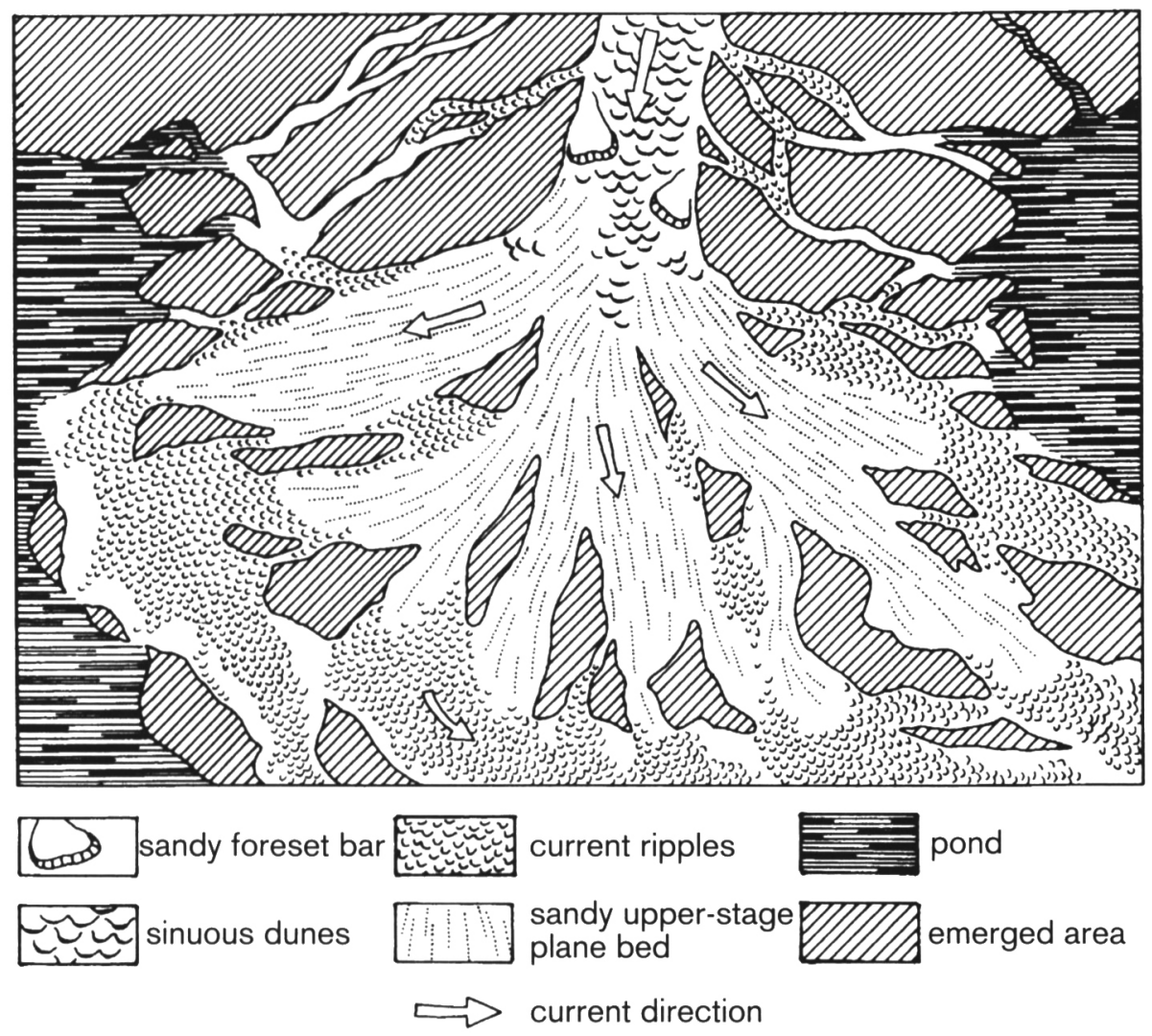

Fig. 7. Generalised palaeoenvironmental model of the distal fan (subenvironment D).

plane-bed conditions (very shallow, distal sheetflows). Silts settle in standing waters. As a rule, these relatively fine-grained deposits cap the successions of the fans and form their margins.

\section{Bed thickness and frequency of erosional surfaces}

The proximal, middle and distal subenvironments have different average bed thicknesses (calculated on the basis of $600-800$ measurements per subenvironment): $85 \mathrm{~cm}, 25 \mathrm{~cm}$ and $15 \mathrm{~cm}$, respectively. This decrease is primarily due to an energy decrease of the currents with increasing distance and thus in their transport capacity; a secondary reason is the increase in the length of the respective subenvironments and thus, because of the cone-like configuration of the fan, the more than exponential increase in the surface area of the three successive subenvironments. In the third place, many beds in the proximal fan are formed by debris flows. Such flows are, as a rule, non-erosional and thus contribute to vertical aggradation. The depositional rate over the entire fan thus decreases gradually from the apex of the fan to its margins.

The difference in sedimentation rate is also expressed in another way: the average energy of currents and floods decreases in a downward direction, yet erosion is relatively unimportant in the proximal fan. This is mainly due to the high concentration of particles in the currents on the proximal fan; such cur- rents have a low erosional capability. An additional reason is that even small decreases in the slope, as well as minor decreases in the current's velocity, induce deposition of particles, so that sedimentation is the dominant process. Erosional processes consequently have a larger net effect in the middle than in the proximal subenvironment. In the distal subenvironment the current's velocity is much lower than that in the proximal and middle subenvironments, so the erosional power becomes so small that its influence is more than compensated for by the - also diminished - sedimentation (Fig. 8). The frequency of erosional surfaces consequently increases from the proximal subenvironment in a down-fan direction to reach an optimum in the middle fan subenvironment, lessening again further down-fan.

\section{Types of transport and sedimentation}

Transport and sedimentation on the fan take place by, in order of decreasing importance, unchannelized transport (including sheetfloods), channelized braided streams and mass transport. Settling from suspension is responsible for most of the other deposits. Other processes are of minor importance or do, in a strict sense, not belong to the sedimentation on fans (e.g. deposition from melting ice after temporary ice advance over the fan). 


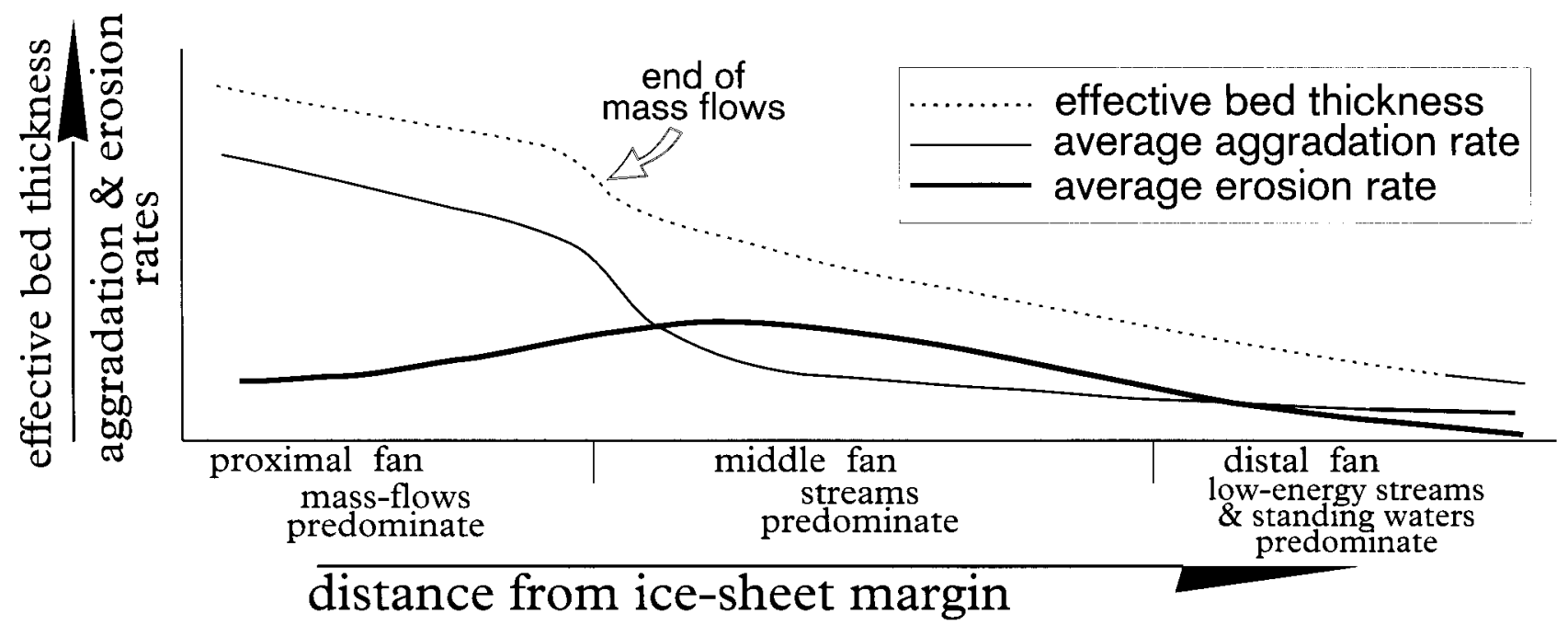

Fig. 8. Schematic diagram of average erosion and deposition rates, resulting in net vertical aggradation, in a longitudinal section of a subaerial terminoglacial fan. Not to scale.

\section{Mass flows}

Mass flows occur on terminoglacial fans under both subaerial and subaqueous conditions. In many cases, mass flows start subaerially and end in pools that develop on the irregular surface of the fan. The massflow process is facilitated by the slope of the fan, the water-saturated character of most sediments, and the presence of sufficient silt- and clay-sized material to act as a lubricant.

The mass flows in the proximal subenvironment are characterised by the frequent presence of large clasts; both the maximum size and the average size of the material transported by mass flow decrease distally. In the most proximal zone, true debris flows prevail; they result in flowtills. The lower-concentration mass flows (fluidal flows) characterise the more distal parts, i.e. the transitional area between the proximal and the middle subenvironments, and result in hyperconcentrated-flow deposits within the channel pattern (see also Zieliński \& Van Loon, 1996).

\section{Unchannelized flows}

A relatively large number of sheet-like layers have a rhythmic character. This may be due to cycles in the ablation, which are characteristic of the terminoglacial zone. The rhythmic successions encountered in a terminoglacial fan are diagnostic of sheetfloods; such frequent, short-lived floods are the dominant transporting agent on these fans - unlike on fans formed under most other conditions, even if the water supply is irregular, as is often the case in an arid climate (see, for instance, Viseras \& Fernández, 1995). The predominance of sheetflows is found particularly in small subaerial terminoglacial fans (up to about 1 $\mathrm{km}$ long).
The rhythmites are generally well developed and show a coarse (gravelly/sandy) character in the proximal subenvironment and a fine (sandy/silty) character in the distal subenvironment. This indicates that the sheetfloods gradually lose their competence when running down from the top of the fan, thus becoming low-energy unchannelized flows.

\section{Channelized currents}

Two types of channelized transport can be distinguished: through relatively deep channels and through braided streams.

Currents in deeply incised channels are most common where sudden floods result in heavy, overloaded flows. Their deposits are found in particular in the proximal fan (subfacies $P-3 b$ ). The channels of this type are usually filled with a mixture of massive, badly sorted gravels, resulting from accretion of coarsegrained sheets in the fan's apex, where channels are truncated frequently.

Other, irregular, channels are shallower and become filled almost exclusively with bars, dunes, plane beds and current ripples indicating a lower flow intensity. This type of channel occurs predominantly in the proximal subenvironment (facies $M-1$ ).

\section{Settling from suspension}

Fine-grained sediments (mainly fine-grained sand to silt) are almost exclusively restricted to the distal fan. They are deposited from low-energy (generally shallow, unchannelized) currents or by settling from suspension in abandoned channels, ponds and small lakes. They obviously represent hydrodynamic conditions from the lower part of the lower flow regime and standing water. 


\section{Overview}

Terminoglacial fans are the only type of fan where the sediments are almost continuously water-saturated owing to a large - though irregular - supply of meltwater, with frequent large floods, apart (perhaps) in winter time. This results in sheetfloods being responsible for most of the vertical accretion. These sheetfloods occur as hyperconcentrated flows in the proximal (rarely in the middle) part of the fans. Individual sheetflood deposits may extend from the highest to the lowest parts. The water-saturated character of the sediments and the abundant presence of debris result in mass flows being common on the proximal fan.

Currents on the proximal fan often have a catastrophic character, like they do - due to fairly similar conditions - on large outwash fans (cf. Smith, 1985; Fraser \& Bleurer, 1988; Maizels, 1992, 1993). This character disappears gradually towards the lower parts, with the result that gravel-bed sheetflows and channels dominate the flows in the proximal fan, whereas sand-bed ones dominate the middle fan.

\section{Discussion}

The genesis of fans under terminoglacial conditions is strongly influenced by the specific situation as regards sediment and water supply, local morphology and granulometry of the parent material. This results in specific characteristics - dealt with below - which are fairly different from those of 'wet' fans, which tend to become shaped in the form of half a cone, with the outline of a Greek capital delta $(\Delta)$. Terminoglacial fans are, as a rule, more irregular because the locations from where water is supplied are highly variable.
Position, growth, size and morphology

The position of subaerial terminoglacial fans is determined by the ice front. A moving ice front thus results in lateral shiftting of the aera where the fans are formed. This has consequences for their groth (aggradation), the size that they may obtain, and their morphology; another consequence is the possible occurrence of cycles, due to alternating phases of ice advance and retreat (apart from cycles due to alternations in hydrological conditions and sediment supply).

\section{Position}

The position of a fan is less fixed under terminoglacial conditions than under more stable conditions: debris may be supplied from various directions (Fig. 9), which tends to make the shape of terminoglacial fans less regular. Since the shape affects the pattern of the distribution of sediment on a fan, the development of terminoglacial fans may differ from that of other alluvial fans.

Another important difference from most other fans is that terminoglacial fans are not static. The ice front moves continuously, however little, which implies that the area where a fan can develop shifts to and fro and that sedimentation at a specific place is more restricted in time than sedimentation on other fans. It is also important in this respect that advancing glaciers tend to destroy not only their marginal moraines (or at least part of them) but also the much less pronounced fans that develop in front of such 'true' moraines, i.e. moraines built of glacial till. Terminoglacial fans thus have a chance of surviving only when the ice front is stable (which is rare) or when it retreats. Retreat im-

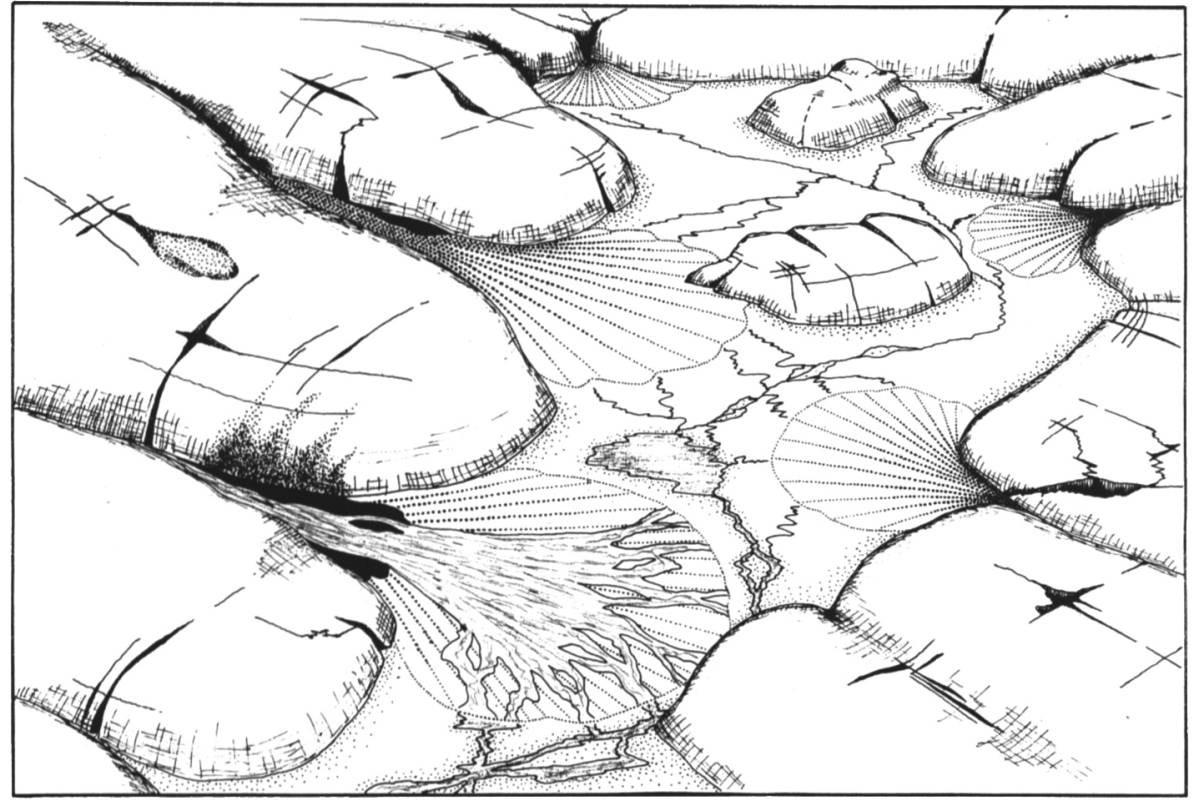

Fig. 9. Characteristic, irregular positions of fans developing in front of the main ice cover (left) and from dead-ice blocks (right). 
plies a relatively short supply of sediment; this is reflected in the generally relatively small size of terminoglacial fans (10-30 m thick, usually 20-25 m; rarely longer than $1.5 \mathrm{~km}$ ).

During the formation of a fan, dead-ice blocks that are covered with and/or contain debris may melt away in the fan area and leave heaps of sediment; in addition, irregular masses of sediment may be left by debris-flows, etc., thus forming new sources of sediment that can be distributed over the fan. This contributes to both the irregular distribution and the irregular character of terminoglacial fans.

\section{Growth rate}

Several authors (among others, Bull, 1964; Beaty, 1970; Graham, 1983; Sadler \& Kelly, 1993; Mackey \& Bridge, 1995; Viseras \& Fernández, 1995) provide estimates of the aggradation rate of the alluvial fans that they studied. All these researchers found relatively low values, in the range of $0.002-2 \mathrm{~cm}$ a year. Only a few authors mention much higher values: Pierson (1980), Langford \& Bracken (1987) Abdullatif (1989) and Beaty (1990) mention $10-100 \mathrm{~cm}$ a year. These higher values are ascribed by the investigators to the particle-rich, high-energy slurries that contribute to the rapid vertical aggradation of debris-flow-dominated fans.

Obviously, the growth rate of the terminoglacial fans under study depends on a wide variety of parameters, important ones being the thickness of the nearby ice (Warren \& Ashley, 1994), the slope of the ice surface (Matthews, 1973; Shreve, 1985), the ablation rate during phases of ice-front stagnation (Sharp, 1951; Gustavson \& Boothroyd, 1987). We estimate the aggradation rate of the small type of terminoglacial fans studied here to be highly variable, with a value of $50-100 \mathrm{~cm}$ a year as a likely average. This estimate is based on the above data, the thickness of the fans (usually 20-25 m) and the period needed for an ice front to retreat so far that it will no longer contribute to the same fan; from observations by the second author in Canada, Iceland and several glaciated mountain ranges, carried out during a timespan of some 25 years, we estimate this period to be $20-50$ years.

\section{Cyclicity in terminoglacial fans}

Cyclicity is a feature typical of fans. Three types are commonly distinguished.

Mega-scale cycles (hundreds of metres thick) are common (Frostic \& Steel, 1993; Kelly, 1993; Leeder, 1993) and large-scale cycles (of several dozens of metres) are even more abundant (Ridgway \& DeCelles, 1993; Lopez-Gomez \& Arche, 1993). Such cycles are usually developed as inversely graded successions (Steel et al., 1977; Crews \& Ethridge, 1993), representing prograding fans. These are long-term allogenic cycles controlled as a rule by tectonic and climatic changes. Such cycles have, to our knowledge, not been described from Pleistocene glacigenic sediments.

Medium-scale cycles are several to a few dozens of metres thick and often show a fining-upward tendency (Casshyap \& Tewari, 1982; Blakey \& Gubitosa, 1984; Sing \& Banerjee, 1991; Fraser, 1993). Most of them are interpreted as an effect of lateral shifting of sedimentary subenvironments on the fans, such as channels and overbank areas (Viseras \& Fernandez, 1995; Jo et al., 1997), channels and playas (Hubert \& Hyde, 1982) or channels and mass-flow areas (Calvache et al., 1997). These cycles can be regarded as records of the the evolution of braided channels and their infillings (the so-called channel cycle of Godin, 1991). This type has been described frequently from both Pleistocene and pre-Pleistocene successions (by, among others, Mader \& Teyssen, 1985; Rust \& Gilbing, 1990; Singh et al., 1993). They should be considered as autogenic cycles because both depositional evolutions and the avulsion of braided channels are autocyclic phenomena (cf. Heward, 1978b; Miall, 1996). Successions of terminoglacial fans usually reflect an upward transition from the proximal into the middle environment, with the distal deposits on top. Each of these units is thinner and finer grained than the underlying material. Cycles are rare, because these fans form and develop very rapidly in response to a melting and retreating ice front. It could therefore also be stated that the lithosomes of these subaerial terminoglacial fans represent seventh-order units in the stratigraphic architecture scheme developed by Miall (1996).

Small-scale cycles form successions ranging from decimetres to some metres thick, and display a finingupward character. They owe their origin to the shortterm evolution of bed and channel forms controlled by changing hydrological conditions (the macroform cycle of Godin, 1991). They consist commonly only of a channel facies and represent waning floods (cf. Fraser, 1993; Zaleha, 1997). Under glaciofluvial conditions, such cycles may be governed by a diurnial hydrological rhythm (Olsen \& Andreasen, 1995). This simple type of cyclicity is, as a rule, well developed in terminoglacial fans.

\section{Slope}

An interesting difference from most other types of fans is that those formed under terminoglacial conditions have a relatively gentle slope, even in their proxi- 
mal parts. Nemec \& Postma (1993) mention a slope of up to $10-12^{\circ}$ for mountainous 'wet' fans, whereas the slope of terminoglacial fans rarely exceeds $2-5^{\circ}$; the latter value is, surprisingly, consistent with that of the type II alluvial fans of Blair \& McPherson (1994b), i.e., with that of semi-arid fans formed by coexisting sheetflows, hyperconcentrated streams and debris flows.

Water supply, channel characteristics and depositional processes

The water supply in the terminoglacial zone is highly irregular. Periods in which there is hardly any supply (e.g., during winters) alternate with periods in which there are large supplies, sometimes of a catastrophic nature (e.g., when an ice barrier damming off a glacial lake breaks through) (see Mokhtari Fard, 1998). A similar (though less pronounced) irregularity in water supply is found only in arid environments, where sudden outbursts of rain may occur. Nemec \& Postma (1993) took the consequences of changes in water supply into account in their subdivision of alluvial fans into three genetic types, dominated by debris flows, stream flows and sieve lobes. This distinction is not suitable for terminoglacial fans, because debris flows and streams coexist on such fans: debris flows dominate the proximal subenvironment, whereas streamflows do so in the middle subenvironment. Sieve-lobe-dominated fans are absent in the terminoglacial zone because truly coarse open-work beds are atypical of this environment and because, moreover, the groundwater table tends to be close to the sedimentary surface.

Several authors (among others Brierley et al., 1993) state that the size of bars in the braided channels on fans increases in a distal direction. We found the opposite, probably as a result of decreasing channel depth. The latter finding (the channels eventually become so shallow that unchannelized flows take over) is consistent with descriptions by Davis (1938), Friend (1978) and Heward (1978a). McGowen \& Groat (1971) state that sandy transverse bars are characteristic of distal alluvial fans, but there are hardly any indications for such bars under terminoglacial conditions: the streams in the distal subenvironment are so shallow that, if channelized flow occurs, the stage of upper plane-bed conditions is reached, so that bars do not develop. In fact, transverse (foreset) sand bars are fairly typical of these braided channels, but only on the middle terminoglacial fan (see facies $M-1$ in Zieliński \& Van Loon, 1998). We ascribe this to the strong aggradational character of channel flows on this part of the fan.
Processes and deposits in the proximal subenvironment The important role of debris flows in the proximal subenvironment contrasts with the models proposed for fans by Miall (1970), Gloppen \& Steel (1981) and Kochel \& Johnson (1984). On the other hand, Brierley et al. (1993) mention debris flows on proximal fans, together with hyperconcentrated flows that they consider characteristic of the proximal zone. We found, however, that hyperconcentrated flows on terminoglacial fans are also present in the middle subenvironment, as indicated by the occurrence of massive clayey sands and clayey/sandy gravels.

\section{Processes and deposits in the middle subenvironment}

In the middle subenvironment, many authors (e.g., Amajor, 1986) interpret abundant deposits as being a result of grain flow. We did not recognise any of such sediments, however, possibly because the mass flows of till material are too cohesive owing to the high percentage of silt and clay; grain flows can develop only in material with very little cohesion or no traceable cohesion at all.

In the middle subenvironment, where braided channels dominate, the currents follow a large number of shallow braided channels; this contrasts with the most common situation on other fans, where the main channel takes most water (cf. Friend, 1978). Whereas Cherven (1984) and Amajor (1986) noted abundant channel-fills up to $2 \mathrm{~m}$ thick in the middle zone, such indications of deep channels are absent in terminoglacial fans. This is a logical consequence of the difference in the system of channels.

In the middle part of polar fans, Catto (1993) found abundant silt and diamict beds in the interchannel areas. They were formed by gelifluction flows of the permafrost active layer. Such redeposition does not occur on terminoglacial fans. They are probably too short-lived and have a too high aggradation ratio, so that the results of slowly acting creep by gelifluction are easily destoyed by faster processes affecting the sedimentary surface. Periglacial phenomena can develop only in the uppermost parts of terminoglacial successions, but are rare even there.

\section{Processes and deposits in the distal subenvironment}

Friend (1978) states that the distal subenvironment of fans is characterised by a system of numerous distributary channels, which is in contrast with our observations that this subenvironment is dominated by unchannelized flows. Our observations with respect to deposition in shallow, ephemeral ponds is consistent with Friend's observations. Our findings are also largely similar to those of Beaty (1990), whose model of the distal subenvironment includes numerous 
sand-bed braided channels and overflows. This is, however, not consistent with the characteristics described by Krigström (1962) and Fahnestock (1963), who state that a single, broad channel dominates in this subenvironment too; these studies, however, concern sandurs (flat, wide braidplains, commonly with a great extent) rather than true glacial fans (much steeper, with a small extent).

The large, deep channels described for distal fans under most climatic conditions explain why gravel beds are considered to be common and why alluvium can be repeatedly reworked by such channels (cf. Blair, 1987). This must be considered in the context of the slope, which tends to be much steeper in other environments than under terminoglacial conditions. The relatively steep slope in other climatic zones also explains why several researchers (among others, McGowen \& Groat, 1971; Harvey, 1984) mention much higher energy levels for the distal fan than are justified for terminoglacial conditions; Harvey (1984) states that up to $80 \%$ of the sediments in the distal subenvironment may consist of fluvial gravel, whereas sand is the coarsest material found in distal terminoglacial fans.

The dominance of unchannelized currents and transport through numerous shallow channels explains why the distal subenvironment of terminoglacial fans does not contain pointbar deposits. Such deposits, which McGowen \& Garner (1970) and Kesel \& Lowe (1987) consider to be characteristic, require large rivers that can develop a sinuous course on large alluvial plains (if the flow is continuous, not intermittent).

\section{Granulometry}

The granulometric characteristics of fans formed under terminoglacial conditions are atypical if compared with those of classical alluvial fans. Whereas fans are usually derived from material that has undergone at least some fluvial sorting (cf. Kochel \& Johnson, 1984), the parent material of terminoglacial fans consists of morainic material, i.e. unsorted tills. A relatively wide range of grain sizes is therefore available, with a high content of particles smaller than sand. The abundance of fine-grained debris-flow deposits (flowtills) on the proximal fan is in contrast with the situation on non-glacial fans. Several authors (among them Beaty, 1963; Amajor, 1986; Brierley et al., 1993; Blair \& McPherson, 1994a) note that the debris-flow deposits on such fans are coarse diamicts, frequently containing boulders; they are interpreted as deposits from cohesionless debris flows.

The difference between our model and that of

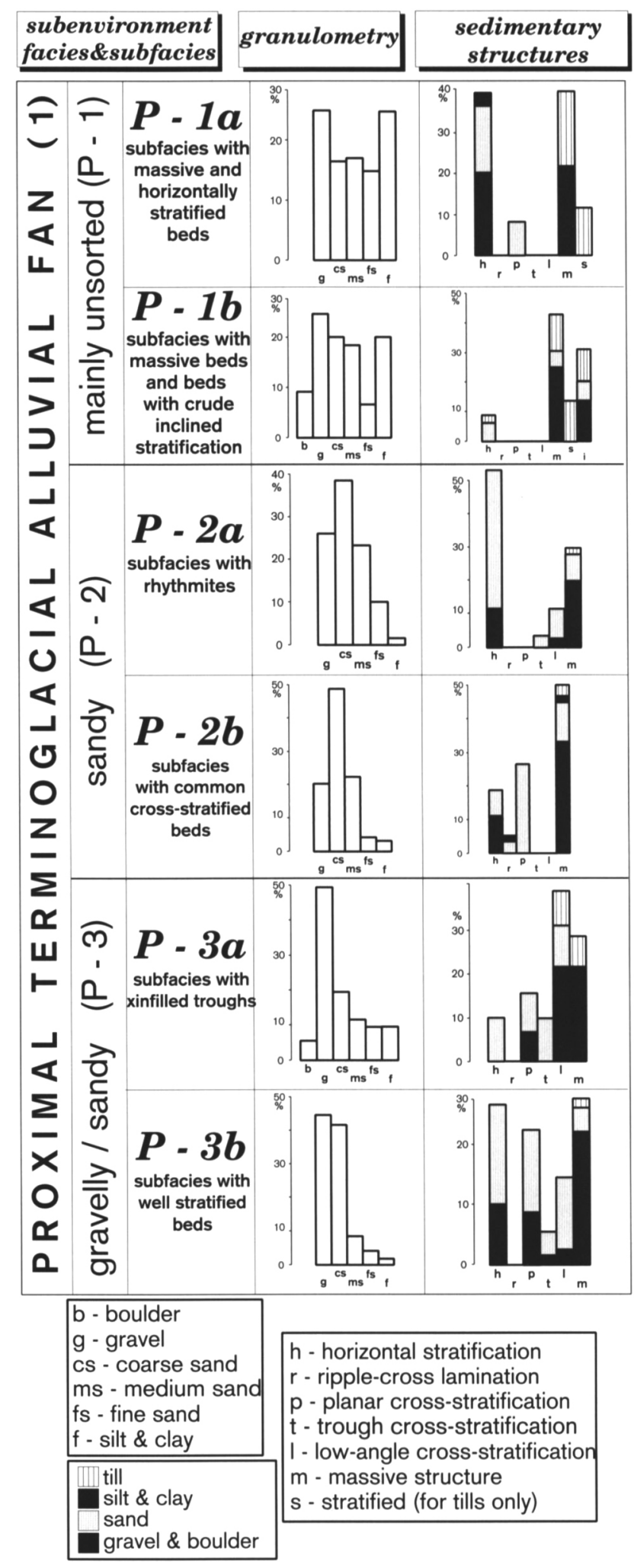

Fig. 10. Average grain size and sedimentary structures in the three subenvironments of the terminoglacials fans under study.

Kochel \& Johnson (1984) for humid-glacial fans may be due to the fact that Kochel and Johnson took large sandurs as the basis for their conclusions. Sandurs may, however, be considered to be large alluvial plains (braidplains) rather than true alluvial fans; we want to 


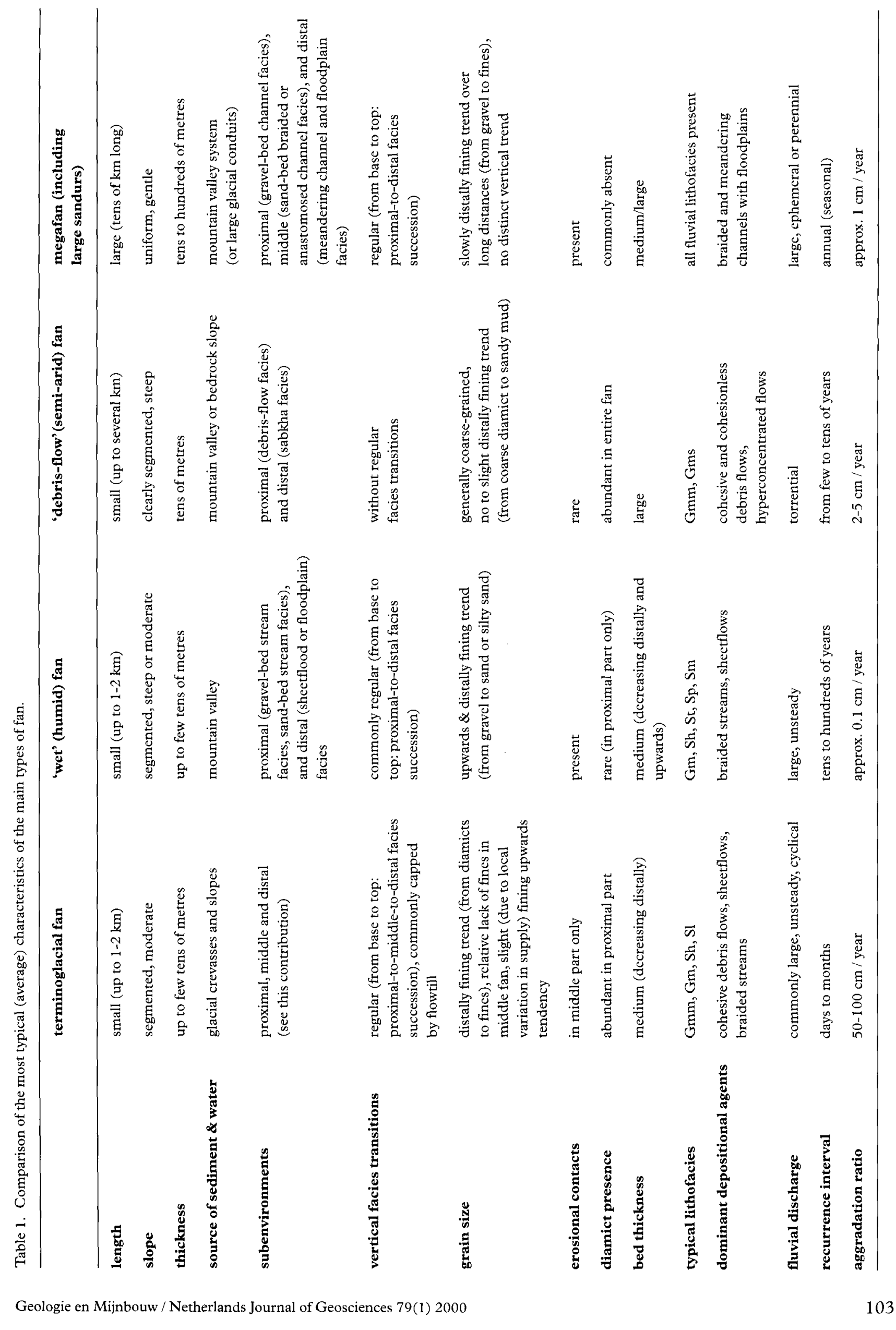


emphasize explicitely that this results in a number of differences between these two types of deposits (cf. Blair \& McPherson, 1994a).

Another remarkable feature is that fans, as a rule, show a gradually decreasing grain size in distal directions. In terminoglacial fans, however, a relative lack of fine-grained material is found in the middle subenvironment (Fig. 10). The presence of more fines in the proximal than in the middle subenvironment must be attributed to the much more frequent occurrence in the former of till-derived (and therefore commonly diamictic) mass-flow deposits.

\section{Conclusions}

The study shows that fans that form under subaerial terminoglacial conditions, with marginal moraines as parent material, are different from most other types of fans (see Blair \& McPherson, 1994a). The major characteristics of fans from different environments are compared in Table 1 . In spite of the many important differences, the subaerial terminoglacial fans have many properties in common with fans from other environments - for instance, the distinct differentiation into a proximal, a middle and a distal subenvironment. A compilation of the most important elements determining the character of subaerial terminoglacial fans is presented in Figure 11.

A specific characteristic of terminoglacial conditions is the irregular - and sometimes huge - supply of water. In combination with the water-saturated character of the unsorted source material (diamicts constituting moraines), this facilitates mass movements. It is therefore interesting that these fans fit the general model of Kochel \& Johnson (1984) for arid alluvial fans rather than the model for humid-glacial fans. It should be noted in this context that fans are generally subdivided into 'wet' and 'dry' fans (Schumm, 1977); the first group is dominated by braided channels, whereas the second group is dominated by mass flows. Terminoglacial fans appear to form an intermediate category. The frequent mass flows result in almost equal amounts of mass-flow and fluvial deposits in the proximal subenvironment; subsequent reworking of part of the mass-flow deposits changes this picture, but the original character

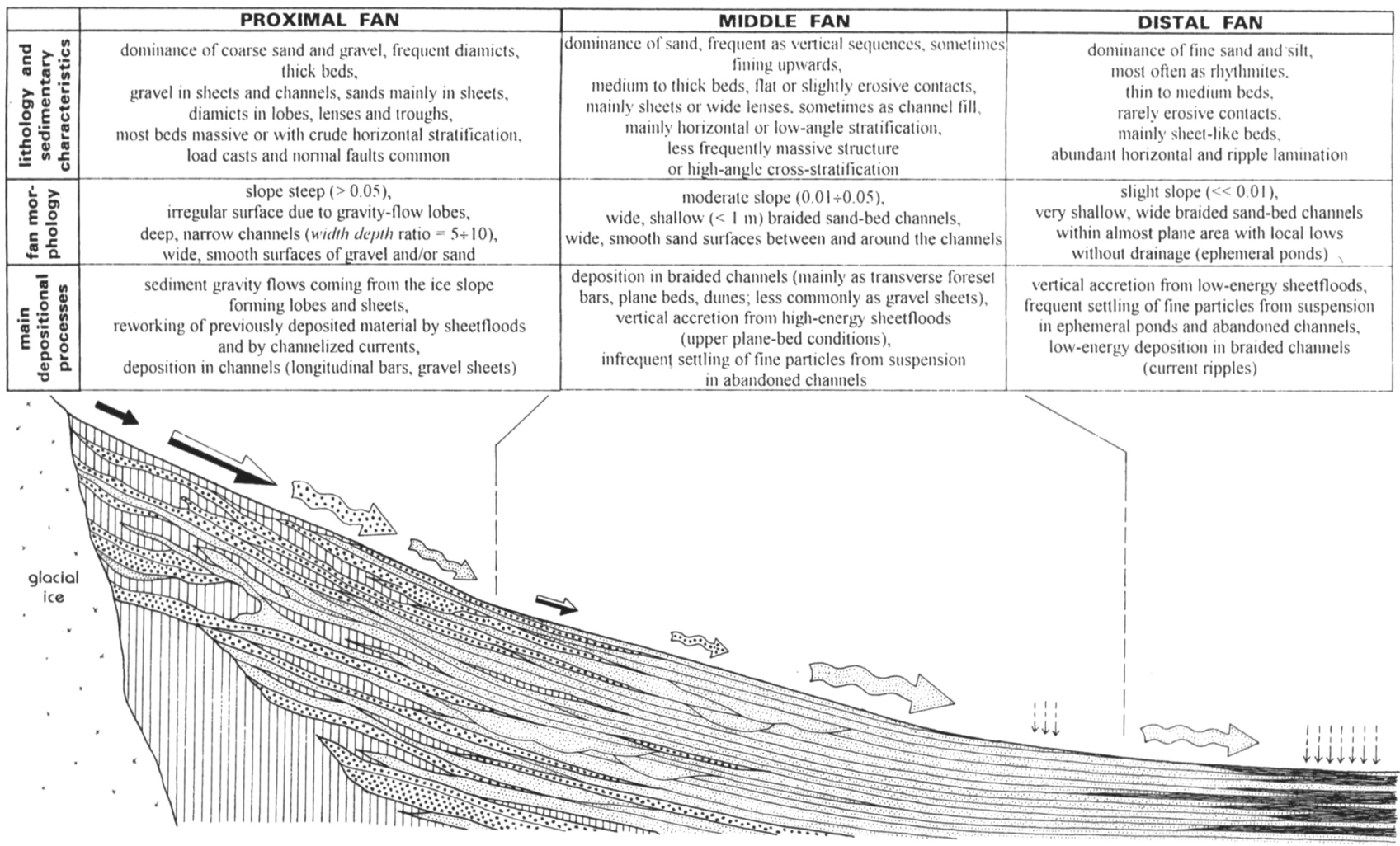

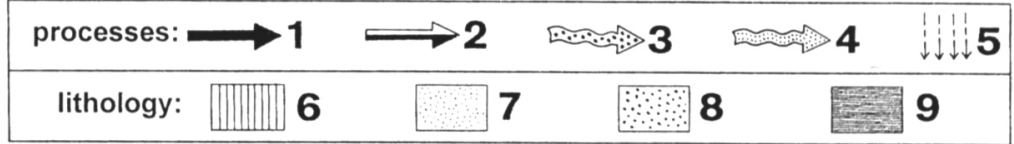

Fig. 11. Compilation of the most important elements determining the characteristics of terminoglacial fans.

$1=$ mass flow; $2=$ fluvial reworking of mass-flow deposits; $3=$ gravel-laden currents; $4=$ sand-laden currents; $5=$ settling from suspension; 6 $=$ till $7=$ sand; $8=$ gravel $; 9=$ silt. Size of arrows indicates relative importance. 
of the reworked mass-flow deposits is usually still traceable, indicating that reworking is only slight in most cases.

The middle subenvironment is dominated not by mass-flow processes but by sedimentation from numerous shallow braided streams and from unchannelized flows. This holds also for the distal subenvironment, but settling of fines in ephemeral ponds also plays a significant part here.

One explanation for the diverging character of the terminoglacial fans is that they tend to stop forming at a stage when they have not had a change to develop completely, because the ice front shifts to and fro. This 'immature' character may be deduced from the following sedimentological observations:

- the fans are rarely over a kilometre long; this might indicate that they stop their development during (or even before) the second phase distinguished by Blair \& McPherson (1994b), whereas the third (final) phase of fan development is the one during which the front of the fan progrades significantly;

- relatively few erosional surfaces are present in terminoglacial fans, whereas erosional channels (particularly in the proximal part) are typical of the last phase of fan development (Hooke, 1967; Blair, 1987; Blair \& McPherson, 1994b);

- the proximal part shows so little erosion activity that only a relatively small amount of particles deposited originally on the proximal fan later reach the middle and distal parts, where aggradation is consequently restricted.

It thus appears that terminoglacial fans never reach a mature stage, but - as a rule - show still juvenile characteristics even at the end of their development. This is in contrast to all other types of fan, which as a rule continue to develop, reaching a mature and even a senile phase. It can thus be concluded that subaerial terminoglacial fans represent a type that 'fossilize' somewhere in the middle of the normal fan evolution.

\section{Acknowledgements}

The first author thanks Richard Collier (University of Leeds, Department of Earth Sciences) for his helpful review of an earlier draft of this contribution. The suggestions by the late Prof. Dr. Krzysztof Brodzikowski (University of Łódź, Department of Geography) are also greatly appreciated. We are also indebted to Liza Crossan (WriteItRight) for long-lasting support and for correcting the English text.

\section{References}

Abdullatif, O.M., 1989. Channel-fill and sheet-flood facies sequences in the ephemeral terminal River Gash, Kassala, Sudan. Sedimentary Geology, 63: 171-184.

Amajor, L.C., 1986. Alluvial fan facies in the Miocene-Pliocene coastal plain sands, Niger delta, Nigeria. Sedimentary Geology, 49: 1-20. Beaty, C.B., 1963. Origin of alluvial fans, White Mts, California ann Nevada. Annals of the Association of American Geographers, 53: 516-535.

Beaty, C.B., 1970. Age and estimated rate of accumulation of an alluvial fan, White Mts., California. American Journal of Science, 268: 50-77.

Beaty, C.B., 1990. Anatomy of a White Mts. debris flow - the making of an alluvial fan. In: A.H. Rachocki and M. Church (eds.): Alluvial fans: a field approach. Wiley \& Sons, Ltd: 69-89.

Blair, T.C., 1987. Sedimentary processes, vertical stratification sequences, and geomorphology of the Roaring River alluvial fan, Rocky Mt. National Park, Colorado. Journal of Sedimentary Petrology, 57: 1-18.

Blair, T.C. \& McPherson, J.G., 1994a. Alluvial fans and their natural distinction from rivers based on morphology, hydraulic processes, sedimentary processes, and facies assemblages. Journal of Sedimentary Research, 64: 450-489.

Blair, T.C. and McPherson, J.G., 1994b. Alluvial fans - processes and forms. In: Abrahams, A.D. \& Parsons, A.J. (eds.): Geomorphology of desert environments. Chapman \& Hall (London): 354-402.

Blakey, R.C. \& Gubitosa, R., 1984. Controls of sandstone body geometry and architecture in the Chinle Formation (Upper Triassic), Colorado Plateau. Sedimentary Geology, 38: 51-86.

Brierley, G.J., Liu, K. \& Crook, K.A.W., 1993. Sedimentology of coarse-grained alluvial fans in the Markham Valley, Papua New Guinea. Sedimentary Geology, 86: 297-324.

Brodzikowski, K. \& Van Loon, A.J., 1987. A systematic classification of glacial and periglacial environments, facies and deposits. Earth-Science Reviews, 24: 297-381

Brodzikowski, K. \& Van Loon, A.J., 1991. Glacigenic sediments (Developments in Sedimentology, 49). Elsevier (Amsterdam): $674 \mathrm{pp}$.

Bryhni, I., 1978. Flood deposits in the Hornelen Basin, W. Norway (Old Red Sandstone). Norsk Geologisk Tidsskrift, 58: 237300.

Bull, W.B., 1964. Alluvial fans and near-surface subsidence in W Frenso County, California. United States Geological Survey Professional Paper, 437-A: 71 pp.

Calvache, M.L., Viseras, C. \& Fernandez, J., 1997. Controls of fan development - evidence from fan morphometry and sedimentology; Sierra Nevada, SE Spain. Geomorphology, $21: 69-84$

Casshyap, S.M. \& Tewari, R.C., 1982. Facies analysis and paleogeographic implications of a Late Paleozoic glacial outwash deposit, Bihar, India. Journal of Sedimentary Petrology, 52: 12431256.

Catto, N.R., 1993. Morphology and development of an alluvial fan in a permafrost region, Aklavik range, Canada. Geografiska Annaler, 75A: 83-93.

Cherven, V.B., 1984. Early Pleistocene glacial outwash deposits in the eastern San Joaquin Valley, California: a model for humidregion alluvial fans. Sedimentology, 31: 823-836.

Crews, S.G. \& Ethridge, F.G., 1993. Laramide tectonics and humid alluvial fan sedimentation, NE Uinta Uplift, Utah and Wyoming. Journal of Sedimentary Petrology, 63: 420-436.

Davis, M.W., 1938. Sheetfloods and streamfloods. Geological Society of America Bulletin, 49: 1337-1416. 
Fahnestock, R.K., 1963. Morphology and hydrology of a glacial stream - White River, Mount Rainer, Washington. United States Geological Survey Professional Paper, 422-A: 70 pp.

Fraser, G.S., 1993. Sedimentation in an interlobate outwash stream. Sedimentary Geology, 83: 53-70.

Friend, P.F., 1978. Distinctive features of some ancient river systems. In: Miall, A.D. (ed.): Fluvial sedimentology. Canadian Society of Petroleum Geologists Memoir, 5: 531-542.

Frostick, L.E. \& Steel, R.J., 1993. Tectonic signatures in sedimentary basin fills: an overview. In: Frostic, L.E. \& Steel, R.J. (eds.): Tectonic controls and signatures in sedimentary successions. International Association of Sedimentologists Special Publication, 20: 1-9.

Gloppen, T.G. \& Steel, R.J., 1981. The deposits, internal structure and geometry in six alluvial fan-fan delta bodies (Devonian, Norway) - a study in the significance of bedding sequences in conglomerates. In: Ethridge, F.G. \& Flores, R.M. (eds.): Recent and ancient non-marine depositional environments: models for exploration. Society of Economic Paleontologists and Mineralalogists Special Publication, 31: 49-69.

Godin, P.D., 1991. Fining-upward cycles in the sandy braided-river deposits of the Westwater Canyon Member (Upper Jurassic), Morrison Fm., New Mexico. Sedimentary Geology, 70: 61-82.

Graham, J.R., 1983. Analysis of the Upper Devonian Munster Basin, an example of a fluvial distributary system. In: Collinson, J.D. \& Lewin, J. (eds.): Modern and ancient fluvial systems. International Association of Sedimentologists Special Publication, 6: 473-483.

Harvey, A.M., 1984. Debris flows and fluvial deposits in Spanish Quaternary alluvial fans - implications for fan morphology. In: E.H. Koster \& R.J. Steel (eds.): Sedimentology of gravels and conglomerates. Canadian Society of Petroleum Geologists, Memoir, 10: 123-132.

Heward, A.P., 1978a. Alluvial fan and lacustrine sediments from the Stephanian A and B (La Magdalena, Ciñera-Matallana and Sabero) coalfields, N. Spain. Sedimentology, 25: 451-488.

Heward, A.P., 1978b. Alluvial fan sequence and megasequence models: with exammples from Westphalian D - Stephanian B coalfields, N. Spain. In: Miall, A.D. (ed.): Fluvial sedimentology. Canadian Society of Petroleum Geologists Memoir, 5: 669-702.

Hubert, J.F. \& Hyde, M.G., 1982. Sheet-flow deposits of graded beds and mudstones on an alluvial sandflat-playa system: Upper Triassic Blomington redbeds, St. Mary's Bay, Nova Scotia. Sedimentology, 29: 457-474.

Jo, H.R., Rhee, C.W. \& Chough, S.K., 1997. Distinctive characteristics of a stream-dominated alluvial fan deposit: Sanghori area, Kyongsang Basin (Early Cretaceous), SE Korea. Sedimentary Geology, 110: 51-79.

Kelly, S.B., 1993. Cyclical discharge variation recorded in alluvial sediments: an example from the Devonian of SW Ireland. In: North, C.P. \& Prosser, D.J. (eds.): Characterization of fluvial and aeolian reservoirs. Geological Sociaty Special Publication, 73: 157-166.

Kochel, R.C. \& Johnson, R.A., 1984. Geomorphology and sedimentology of humid-temperate alluvial fans, central Virginia. In: Koster, E.H. \& Steel, R.J. (eds.), Sedimentology of gravels and conglomerates. Canadian Society of Petroleum Geologists Memoir, 10: 109-122.

Krigström, A., 1962. Geomorphological studies of sandur plains and their braided rivers in Iceland. Geografiska Annaler, 44: 328-346.

Langford, R. \& Bracken, B., 1987. Medano Creek, Colorado, a model for upper-flow-regime fluvial deposition. Journal of Sedimentary Petrology, 57: 863-870.
Leeder, M., 1999. Sedimentology and sedimentary basins - from turbulence to tectonics. Blackwell Science Ltd. (Oxford): 592 pp.

Leeder, M.R., 1993. Tectonic controls upon drainage basin development, river channel migration and alluvial architecture: implications for hydrocarbon reservoir development and characterization. In: North, C.P. \& Prosser, D.J. (eds.): Characterization of fluvial and aeolian reservoirs. Geological Society Special Publication, 73: 7-22.

Lopez-Gomez, J. \& Arche, A., 1993. Architecture of the Canizar fluvial sheet sandstones, Early Triassic, Iberian ranges, E Spain. International Association of Sedimentologists Special Publication, 17: 363-381.

Mackey, S.D. \& Bridge, J.S., 1995. Three-dimensional model of alluvial stratigraphy: theory and application. Journal of Sedimentary Research, B65: 7-31.

Mader, D. \& Teyssen, T., 1985. Paleoenvironmental interpretation of fluvial red beds by statistical analysis of paleocurrent data; examples from Buntsandstein (Lower Triassic) of the Eiffel and Bavaria in the Germany Basin (middle Europe). Sedimentary Geology, 41: 1-74.

McGowen, J.H. \& Garner, L.E., 1970. Physiographic features and stratification types of coarse grained point bars: modern and ancient examples. Sedimentology, 14: 77-111.

McGowen, J.H. \& Groat, C.G., 1971. Van Horn Sandstone, W. Texas: an alluvial fan model for mineral exploration. University of Texas, Report of Investigations, 72: 1-57.

Miall, A.D., 1970. Devonian alluvial fans, Prince of Wales Island, Arctic Canada. Journal of Sedimentary Petrology, 40: 556-571.

Miall, A.D., 1996. The geology of fluvial deposits. Sedimentary facies, basin analysis, and petroleum geology. Springer (Berlin etc.): 582 pp.

Mokhtari Fard, A., 1998. Rapid deglaciation and ice sheet retreat in the Stockholm area, Sweden - a sedimentological perspective. Quaternaria Stockholm University, A-4.

Nemec, W. \& Postma, G., 1993. Quaternary alluvial fans in southwestern Crete: sedimentation processes and geomorphic evolution. In: Marzo, M. \& Puigdefábregas, C. (eds.): Alluvial sedimentation. International Association of Sedimentologists Special Publication, 17: 235-276.

Olsen, H. \& Andreasen, F., 1995. Sedimentology and ground-penetrating radar characteristrics of Pleistocene sandur deposits. Sedimentary Geology, 99: 1-15.

Pierson, T.C., 1980. Erosion and deposition by debris flows at Mount Thomas, N Canterbury, New Zealand. Earth Surface Processes, 5: 227-247.

Ridgway, K.D. \& DeCelles, P.G., 1993. Stream-dominated alluvial fan and lacustrine depositional systems in Cenozoic strike-slip basins, Denali fault system, Yukon Territory, Canada. Sedimentology, 40: 645-666.

Rust, B.R. \& Gilbing, M.R., 1990. Braidplain evolution in the Pennsylvanian South Bar Fm., Sidney Basin, Nova Scotia, Canada. Journal of Sedimentary Petrology, 60: 59-72.

Sadler, S.P. \& Kelly, S.B., 1993. Fluvial processes and cyclicity in terminal fan deposits: an example from the L. Devonian of SW Ireland. Sedimentary Geology, 85: 375-386.

Schumm, S.A., 1977. The fluvial system. Wiley \& Sons (New York): $338 \mathrm{pp}$.

Selby, M.J., 1994. Hillslope sediment transport and deposition. In: Pye, K. (ed.): Sediment transport and depositional processes. Blackwell Scientific Publications (Oxford): 61-87.

Singh, A. \& Bhardwaj, B.D., 1991. Fluvial facies model of the Ganga River sediment, India. Sedimentary Geology, 72: 135-146.

Singh, A., Bhardwaj, B.D. \& Ahmad, A.H.M., 1993. Tectonic setting and sedimentology of Ganga River sediments, India. Boreas, $22: 38-46$. 
Steel, R.L., Maehle, S., Nilsen, H. Røe, S.L. \& Spinnangr, A., 1977. Coarsening-upward cycles in the alluvium of Hornelen Basin (Devonian), Norway: sedimentary response to tectonic events. Geological Society of America Bulletin, 88: 1124-1134.

Viseras, C. \& Fernández, J., 1995. The role of erosion and deposition in the construction of alluvial fan sequences in the Guadix Formation (SE Spain). Geologie en Mijnbouw, 74: 21-33.

Went, D.J., Andrews, M.J. \& Williams, B.P.J., 1988. Processes of alluvial fan sedimentation, basal Rozel Conglomerate Fm., La Fête des Houghes, Jersey, Channel Islands. Journal of Geology, 23: 75-84.

Zaleha, M.J., 1997. Fluvial and lacustrine palaeoenvironments of the Miocene Siwalik Group, Khaur area, N Pakistan. Sedimentology, 44: 349-368.

Zielinski, T. \& Van Loon, A.J., 1996. Characteristics and genesis of moraine-derived flowtill varieties. Sedimentary Geology, 101: 119-143.

Zieliński, T. \& Van Loon, A.J., 1998. Subaerial terminoglacial fans I: a semi-quantitative sedimentological analysis of the proximal environment. Geologie en Mijnbouw, 77: 1-15.

Zieliński, T. \& Van Loon, A.J., 1999. Subaerial terminoglacial fans II: a semi-quantitative sedimentological analysis of the middle and distal environments. Geologie en Mijnbouw, 78: 73-85. 